\title{
L'armonia del linguaggio dei Giardini Paesaggistici nell'Europa di fine '700
}

\author{
Domenico Crispino \\ Luigi Corniello
}

Abstract

Oggetto della ricerca sono le matrici metodologiche poste alla base della realizzazione di alcuni tra i giardini paesaggistici siti in territorio europeo al termine del Settecento. Attraverso lo studio dell'apparato grafico e teorico costruito nel corso del medesimo secolo, vengono analizzati il parco del Petit Trianon di Versailles, il parco Reale di Laeken a Bruxelles, il Regno-Giardino di Wörlitz a Dessau e il Jardin del Principe di Aranjuez al confine meridionale della Comunità di Madrid. I casi studio presentano un palinsesto di elementi analoghi riferibili sia alla rete di rapporti che costituisce il trait d'union tra i committenti sia ad alcuni principi fondamentali enunciati da autori inglesi quali Walpole e Gilpin. Le peculiarità emerse delle fonti, ascrivibili ai due autori britannici, consistono nell'articolazione delle loro opere che dichiaratamente non intendono legarsi al ricco corpus della trattatistica formulata in quel periodo circa l'impianto tipologico del giardino moderno. Entrambi espongono i tratti distintivi di tale nuova categoria, liberandosi dalla ricerca della descrizione oggettivizzante propria della trattatistica, arricchendo le loro dissertazioni con un'ampia gamma di impressioni e pareri soggettivi in grado di restituire una rappresentazione sicuramente parziale ma maggiormente efficace dei singoli elementi. L'obbiettivo del presente studio è esaminare, attraverso le metodologie proprie della disciplina del disegno, gli elementi messi in luce dalle descrizioni degli autori e individuabili all'interno dei siti in analisi, dimostrando la capacità assunta dai singoli elementi nel conferire alla tipologia i propri caratteri identitari.

Parole chiave

linguaggi, paesaggio, disegno, giardino, palinsesto.

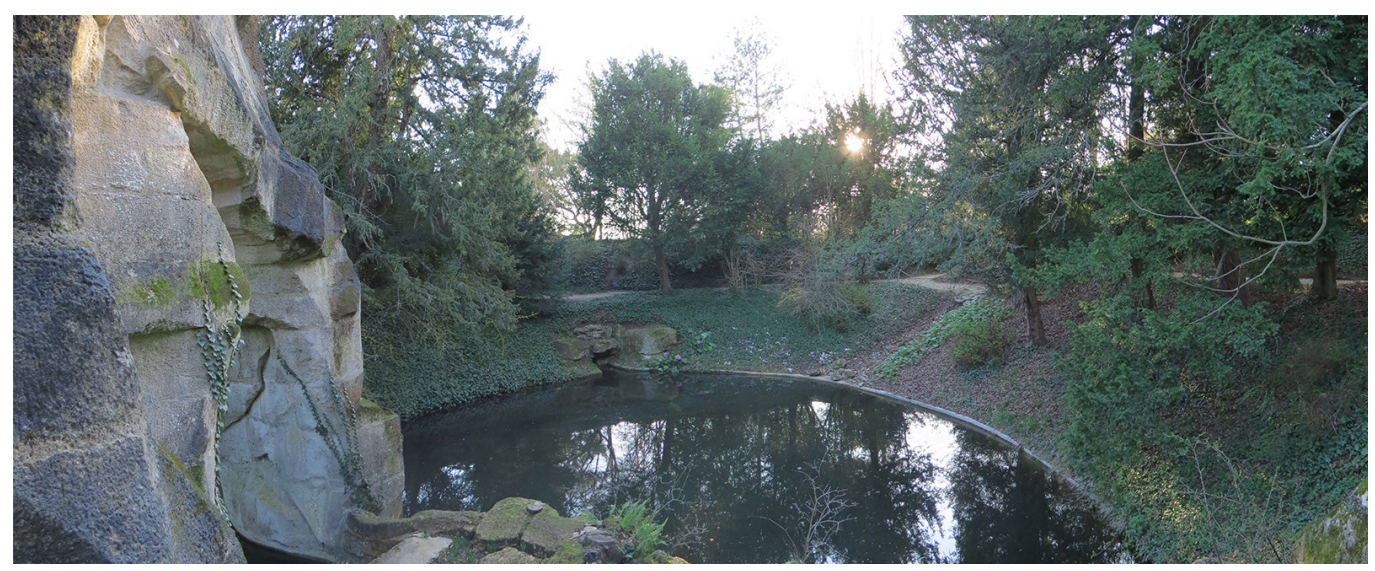




\section{Introduzione}

II giardino di paesaggio concepito in antitesi all'impianto classico di tipo architettonico, si afferma in Europa alla fine del XVIII secolo. Partendo dalle esperienze inglesi, ai quali viene riconosciuta la paternità di questo peculiare impianto tipologico, è possibile distinguere una gamma di efficaci applicazioni diffusa nell'intero continente e declinata attraverso le differenti condizioni morfologiche climatiche e ambientali offerte dalle specificità dei contesti individuati per ospitare i landscape gardens. Le diversità esplicitate dall'analisi e dal confronto posti in essere tra i vari siti risultano tuttavia riconducibili a un'analoga matrice tipologica riferibile alla metodologia del giardino all'inglese.

L'obiettivo dello studio è quello di approfondire la conoscenza dei legami teorici e metodologici posti alla base della rete di informazioni, già presente nel Settecento, e impiegata per la diffusione pratica dell'apparato teorico e morfologico. I siti sottoposti a questo studio in apparenza lontani ed eterogenei sono, al contrario, strettamente connessi da una rete che lega le committenze unitamente ai progettisti e i teorici che hanno dato luogo alla realizzazione dei giardini.

La ricerca vuole rintracciare, attraverso l'analisi delle fonti documentarie e grafiche, l'effettiva esistenza della rete costituita, in primo luogo, dall'ossatura metodologico trattatistica posta alla base comune di formazione del pensiero relativo al giardino moderno e, successivamente, individuare gli scambi di informazioni esperienze e professionalità che consentono sul finire del secolo dei lumi di redigere un vasto catalogo di differenti esperienze legate al giardino paesaggistico ma riconducibili a un unico corpus disciplinare chiaramente distinguibile e con dei caratteri fortemente identitari.

La presenza una forte componente teorica sostanziata negli scritti di diversi autori settecenteschi [Walpole 1785, Gilpin 1748] rende verificabile l'esistenza di una complessa gamma di elementi realizzati nei giardini paesaggistici riferibili alla comune radice trattatistica e in grado di costituirsi come elementi di chiara riconoscibilità tipologica. La ricerca si sviluppa sulla scorta dei molteplici contributi scientifici che costituiscono una fertile base dalla quale è possibile attingere dati e riscontrare la presenza di connessioni e mutue influenze nella realizzazione dei siti oggetto di studio quali il Petit Trianon di Versailles [Duvernois 2008, Lablaude 1995], il Parc Royal de Laeken di Bruxelles [Van Ypersele de Strihou 1991, Oers 20 I6], il Regno-Giardino di Wörlitz [Giordano 2018; Giordano 2019; Giannetti 2020] e il Jardin del Principe di Aranjuez [Álvarez De Quindós 1804; Chías Navarro, Abad 2019].

Fig. I. Landerer F., II parco Reale di Laeken, Plan Perspectif de la Campagne de

Scoonenberg pres de Scoonenberg pres de Buxelles appartenante a des Pays Bas, 1780. des Pays Bas, 1780

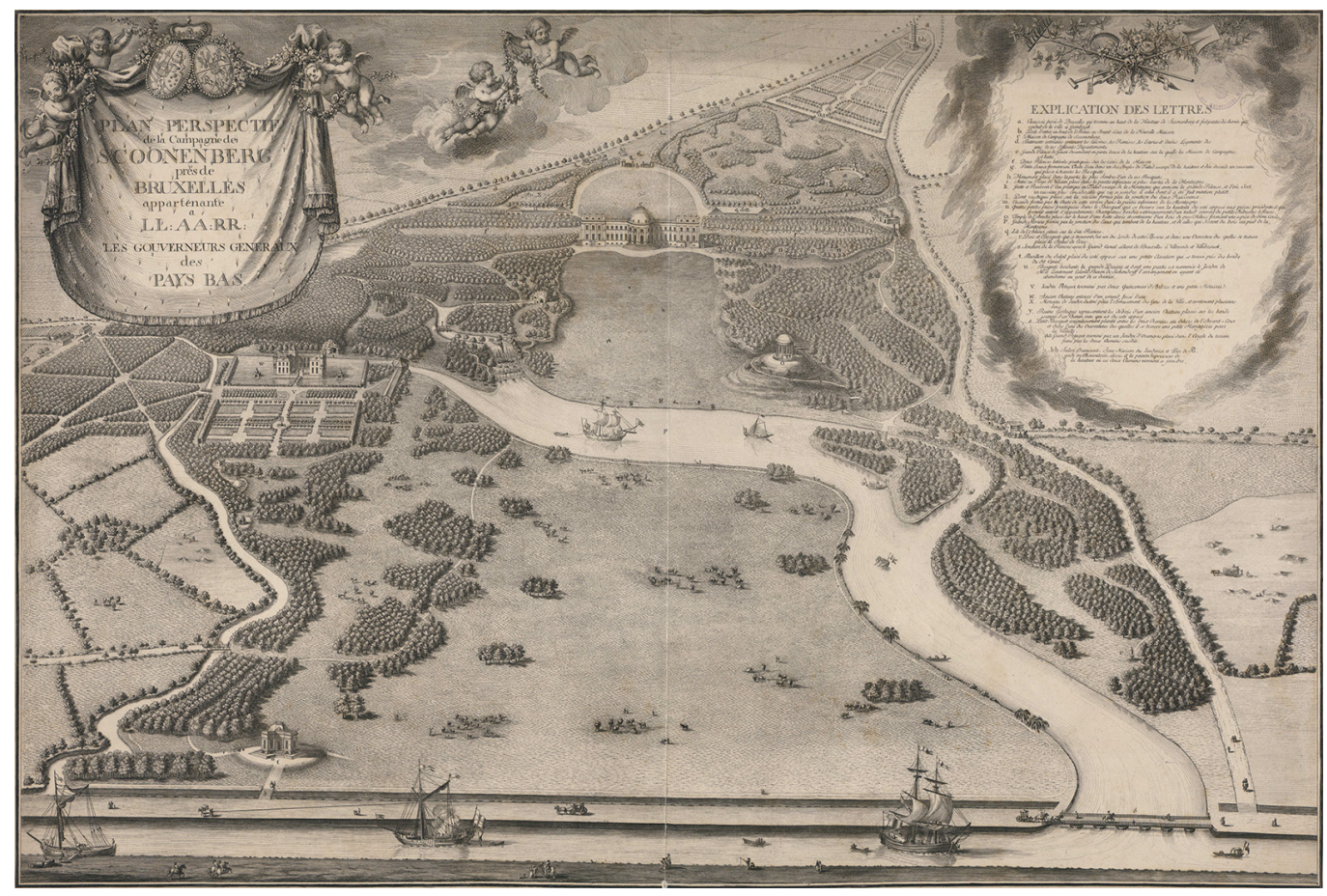




\section{L'analisi delle fonti teoriche}

La ricerca propone l'analisi delle fonti teoriche settecentesche e individua all'interno dei siti in oggetto gli elementi distintivi attraverso gli strumenti disciplinari del disegno per la conoscenza del territorio, del paesaggio e del patrimonio culturale [Clément 20 I3; Cundari 1998; Giordano 20 I8b]. L'Essay on Modern Gardening [Walpole 1785] si costituisce come un testo la cui disamina assume particolare valore per la corretta comprensione del processo evolutivo che ha interessato la materia del giardino nel periodo compreso tra il XVII e il XIX secolo. II testo nella sua traduzione italiana [Franci, Zago I99I] si presenta come una trattazione che ricerca le origini della moderna concezione del giardino arrivando a individuarne i prodromi nel periodo classico. L'autore conduce una critica affilata al giardino di tipo architettonico mettendo in risalto i parossismi che ne hanno costruito nel tempo l'ossatura metodologica. La ricerca procede all'individuazione dei fondatori del pensiero sul giardino moderno attraverso l'analisi della sequenza di successivi affinamenti e riletture che conducono alla definizione teorica, metodologica e applicativa del giardino moderno, la cui prima radice viene rintracciata nell'opera del latino Tacito. II Walpole, in riferimento a quanto riportato negli Annales, asserisce che Nerone "aveva scoperto il vero buon gusto e aveva anche scoperto due uomini di vero genio capaci di mettere in esecuzione le sue idee più audaci. Queste sue idee avevano anticipato i principi estetici del giardino moderno" [Franci, Zago 199I, p. 105]. La trattazione evidenzia come tale primordiale impulso di impostazione tipologica venga dimenticato e sostituito successivamente dal giardino di tipo architettonico, esso assume una rilevanza crescente rendendo necessaria nel Settecento la realizzazione di una critica capace di innescare il processo di cambiamento verso il giardino moderno. I principali fautori del passaggio dall'antico giardino architettonico, alla francese o all'italiana, al moderno giardino di paesaggio, all'inglese, vengono individuati nelle figure di Bridgeman e Kent. Al primo viene ascritta la scoperta e l'impiego di un nuovo dispositivo di perimetrazione che sostituisce al muro un fossato ugualmente invalicabile ma meno riconoscibile. L'impiego di questo sistema innovativo chiamato ah-ah assume il principale effetto di consentire al giardino di fondersi col paesaggio circostante. L'impiego di un apparato analogo è reperibile nei perimetri dei diversi parchi oggetto della ricerca.

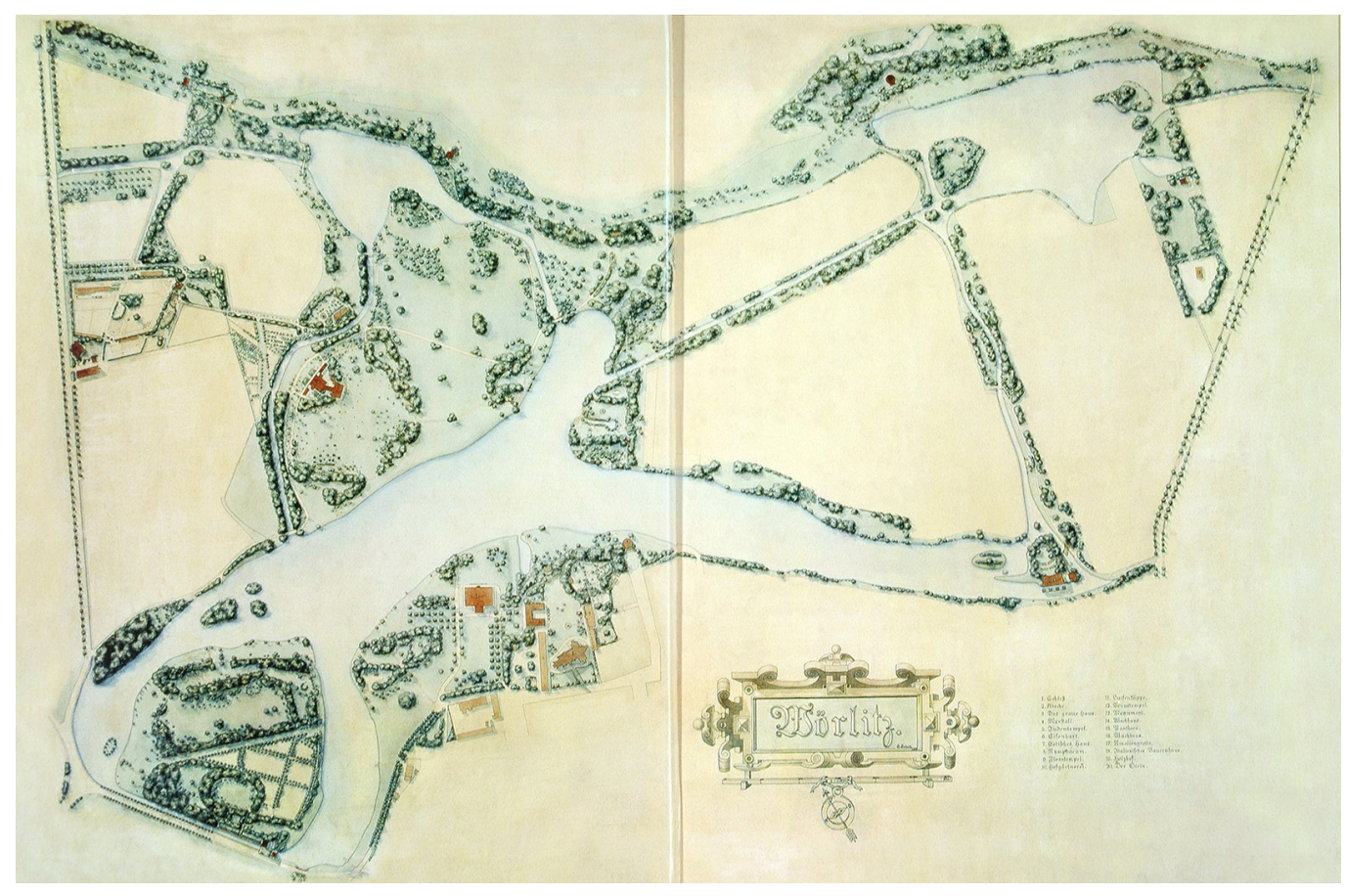


A Versailles nel Petit Trianon l'apparato di definizione del perimetro si articola nella compresenza di ah-ah, salti di quota e muri perimetrali fisici. Tale gamma eterogenea di sistemi di separazione concorre alla realizzazione di un cordone invalicabile che al contempo consente, dove il paesaggio circostante manifesta la capacità di arricchire il palinsesto, di travalicare con lo sguardo il limite fisico del parco e unire ambiente e giardino in un'unica scena.

II Jardin del Principe di Aranjuez, poco a sud della capitale spagnola individua i suoi limiti chiaramente descritti nella parte meridionale dalla recinzione che lo separa da Calle de la Reina e a settentrione dalla presenza del fiume Tago. II corso d'acqua, pur non configurandosi come un ah-ah di accezione canonica riconducibile all'opera di Bridgeman a Stowe, assolve alla medesima funzione, consentendo al paesaggio presente sulla sponda opposta del fiume di insinuarsi tra i giochi di vegetazione delle sezioni parco in maggior misura orientate verso la tipologia del giardino moderno. L'utilizzo dell'acqua come barriera invisibile consente al territorio circostante di porsi come un complemento irrinunciabile degli scenari offerti dal landscape garden. L'operato di Kent si distingue per il sapiente impiego delle acque e l'adozione innovativa di disposizioni orografiche e vegetazionali. In relazione alle acque, l'architetto inglese rifiuta l'impiego di canali rettilinei, bacini geometrici e fontane e reinserisce nel palinsesto del parco l'acqua nel suo stato di ameno ruscello in grado di insinuarsi con naturalezza tra le pieghe del terreno. Riguardo la disposizione del suolo e delle essenze arboree Kent "seppe fare il grande balzo e capì che tutta la natura era un giardino. Egli sentì l'incantevole contrasto fra valle e collina laddove impercettibilmente l'una si cangia nell'altra, assaporò l'incanto di una dolce convessità o di un concavo avvallamento, prese nota del modo in cui boschetti incolti coronavano una dolce altura con felice grazia; e mentre incorniciavano lontane vedute fra i loro armoniosi fusti, al tempo stesso, per illusione ottica, ne spostavano ed estendevano la prospettiva" [Franci, Zago 199I, p. 84]. La moderna concezione riguardo l'uso delle masse d'acqua impiegate per la consecuzione di sistemazioni tendenti verso le forme nelle quali la natura si mostra efficacemente applicata, assume espressione attraverso l'azione progettuale di Lancelot Brown allinterno del Parco di Laeken. II corso d'acqua taglia trasversalmente il parco assume al centro il tono laconico di un sinuoso canale dopo essere stato nella sezione precedente una fragorosa cascata generata attraverso un salto di quota tra il braccio superiore del canale e il suo seguito. L'acqua termina il suo percorso nel progetto di Brown ricongiungendosi al canale navigabile che costituisce il margine sudorientale

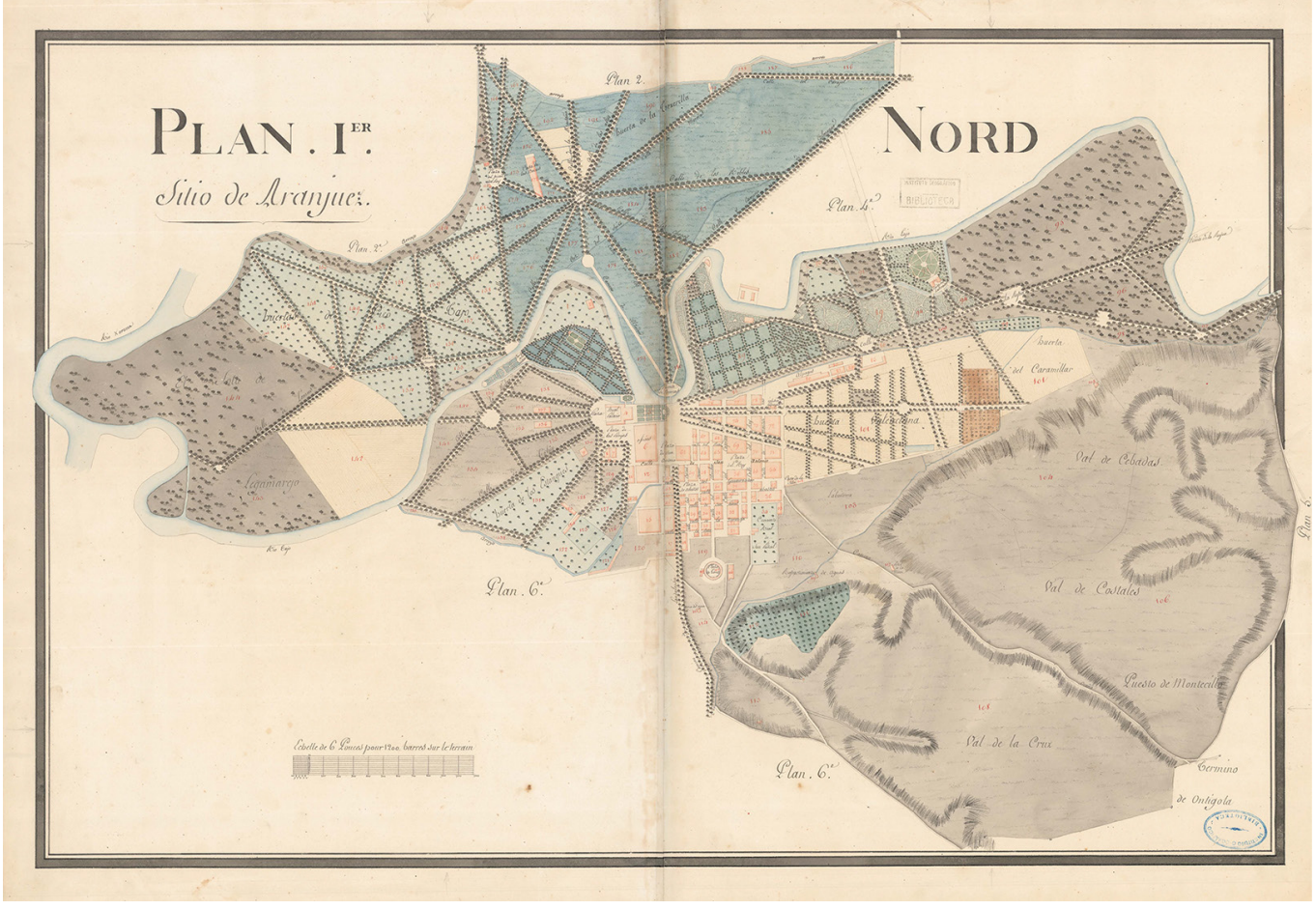


del giardino. II progetto del parco in accordo con le esperienze di Kent sfrutta il declivio naturale del suolo tra il punto in cui è posizionata la residenza e il canale navigabile. L'efficace cornice proposta dalla naturale orografia del suolo viene arricchita da Brown attraverso il posizionamento organico di gruppi arborei che lasciano in comunicazione diretta, attraverso la radura principale, gli elementi centrali periferici ed esterni del parco e costituiscono due quinte armoniche che orientano la prospettiva.

A Versailles, invece, la realizzazione del PetitTrianon comporta la movimentazione di notevoli masse di terreno per conferire al suolo brullo e pianeggiante la quantità di moto necessaria ad articolare scene ideate per l'allestimento del lieu du plaisir di Maria-Antonietta. L'uso ponderato di un suolo dall'orografia complessa arricchito dall'impiego di un'ampia gamma di essenze arboree e dall'articolazione delle acque in una rete di canali, bacini, ninfei e isolotti rende possibile inscenare l'ampio spettro di paesaggi suggeriti dall'osservazione della natura. Le scene si sovrappongono e gli elementi vivi e indipendenti del paesaggio lontano si costituiscono come sfondo perpetuamente mutevole del palinsesto organizzato dal paesaggista. Englefield è il primo teorizzatore di questo concetto, "egli scelse con singolare buon gusto quello che costituisce la maggior bellezza di un giardino, il panorama e gli scorci più felici. [...] Un bel panorama animato è la scena che sarà sempre più frequentata, sacrificata in passato all'utile e al confortevole" [Franci, Zago 199I, pp. 95, 96]. Allo scopo di rendere manifesto e percepibile il panorama circostante, in tutti i siti oggetto di questo studio è possibile individuare dei punti di vista preferenziali che concretizzano l'unione tra parco e contesto. I siti diVersailles e Aranjuez realizzano dei piccoli rilievi alla cui sommità è posta nel caso francese un piccolo punto di osservazione che mette in comunicazione visiva la prima sezione del giardino all'inglese con l'edificio del Petit Trianon e il Parco Reale sullo sfondo; nel caso spagnolo il coronamento consta di un piccolo padiglione in legno di stile neogotico che mette in relazione gli elementi del giardino con il fiume che ne costituisce il limite.

Fig. 4. Kraff J. Ch, Il parco Reale di Versailles, Plan général du jardin français et pittoresque du grand et petit Trianon exécuté près la ville de Versailles persalles, appartenant a Sa Majesté tria Petit Trianon, 1810.

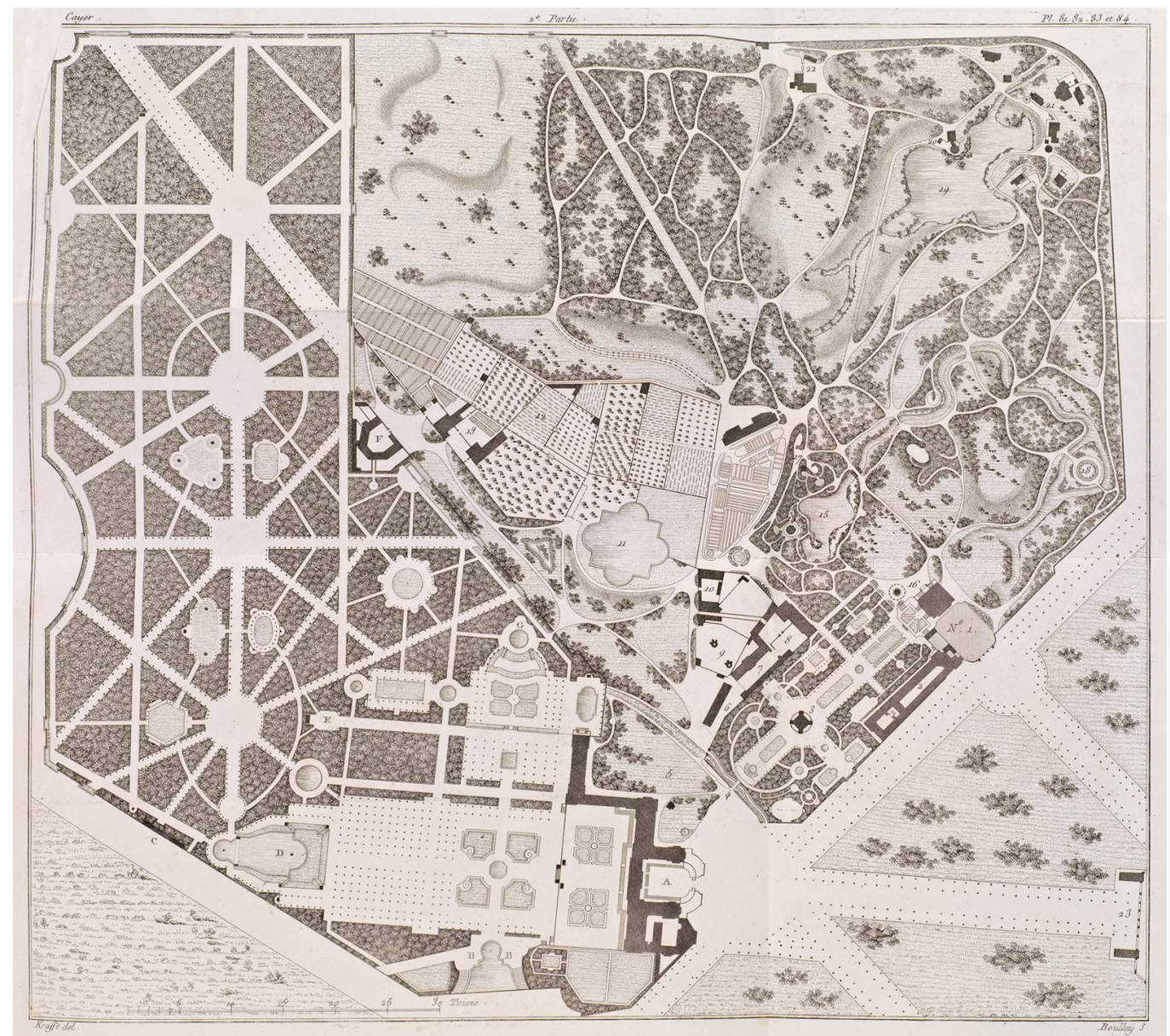




\section{Forme e processi nelle vedute del Settecento}

L'evoluzione disciplinare del giardino moderno innesca un processo di mimesi attraverso il quale, gli architetti nello studio e nell'impianto di nuovi parchi tentano di emulare gli effetti che il paesaggio naturale suggerisce. Tale sviluppo si rende realizzabile attraverso un processo di ricerca teso a celare gli artefatti che rendono attuabile la riproduzione. II principio fondamentale di questa peculiare pratica viene formulato dall'autore il quale stabilisce che "il creatore del giardino moderno esercita tutto il suo talento nel nascondere la sua arte" [Franci, Zago I991, p. 92]. L'elemento della mimesi è dichiaratamente di difficile individuazione, i giardinieri e gli architetti del paesaggio hanno posto tutta la loro capacità ed esperienza nell'esercizio relativo all'occultamento di particolari i quali, anche in seguito alla più acuta osservazione, avessero potuto rendere manifesta la natura artificiale dei dispositivi posti in essere.

Un efficace esempio degli sforzi prodotti in questo senso è individuabile attraverso l'analisi del Rocher posto al lato del bacino del Belvedere all'interno dei giardini del Petit Trianon dove "le fatture degli archivi attestano diversi versamenti di denaro per la tinteggiatura del Rocher. Se si fa riferimento a ciò che è stato fatto in giardini simili, tale lavorazione venne eseguita in trompe-l'oeil con il colore del muschio per nascondere i giunti di malta tra i conci e per mascherare l'aspetto troppo nuovo della costruzione" [Duvernois 2008, pp. 31-34]. II Dialogue upon the gardens of the Right Honourable the Lord Viscount Cobham [Gilpin 1748] assume particolare rilievo in funzione della peculiare visione critica che offre del landscape garden. L'analisi dei temi posti avviene ingegnosamente attraverso le posizioni divergenti dei due protagonisti. Tra gli aspetti di maggiore interesse vi è la considerazione secondo la quale il giardino di paesaggio inscena "un'esperienza di sottili e ben orchestrate sollecitazioni visive necessarie alla decodifica dei monumenti" [Orestano 2003, p. 297]. Emerge dunque la connotazione di pittoresco quale elemento in grado di attrarre l'attenzione dello spettatore.

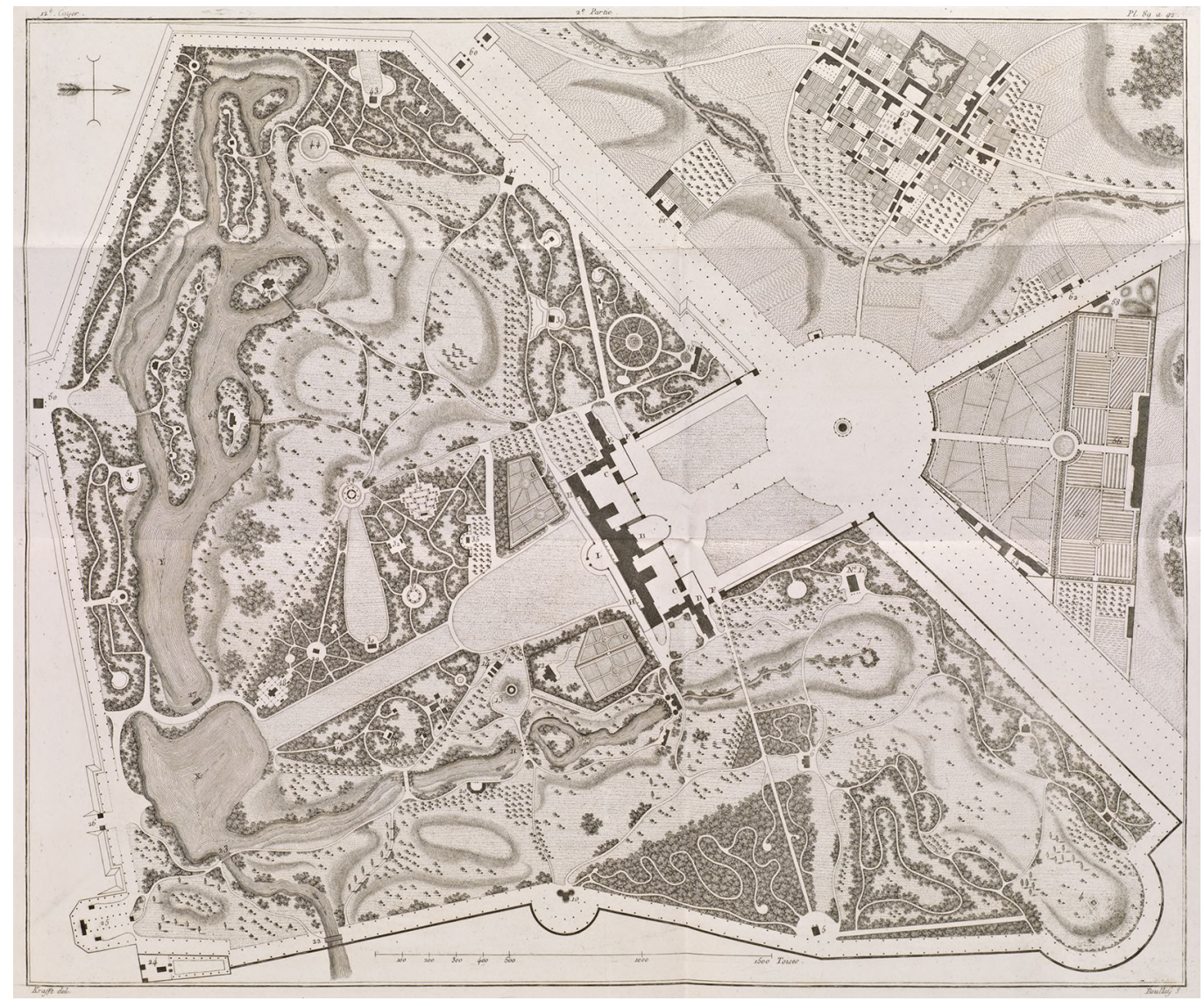


Fig. 6. Il parco del Petit Trianon di Versailles, il dispositivo Ah-Ah impiegato per la delimitazione del confine sudorientale vista (Foto D. Crispino, 2017)

Fig. 7. II parco del Petit Trianon diVersailles, il dispositivo Ah-Ah mpiegato in soluzione continuita con it muro di confine lungo limite settentrionale, vista (Foto D. Crispino, 2017).

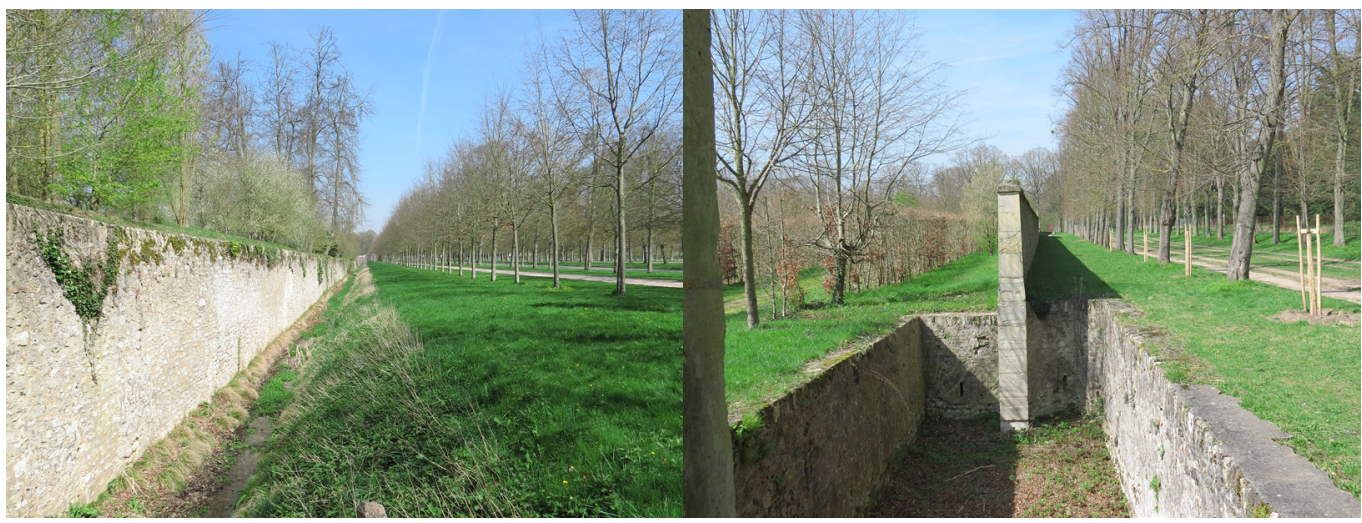

All'interno del Dialogue questo termine appare attraverso la voce di Polypthon quando in prossimità del lago degli undici acri scorge un oggetto sulla riva opposta che lo colpisce: "I think the Ruin a great Addition to the Beauty of the Lake. There is something so vastly picturesque and pleasing to the Imagination in such Objects, that they are a great Addition to every Landskip" [Gilpin 1748, pp. 4, 5].

II termine pittoresco, legato da queste affermazioni al concetto di rovina, diventa "il punto di un dibattito che non ha per oggetto il bello, ma l'effetto strano, intrigante, pittoresco appunto, che l'imperfezione suscita in chi guarda. [...] Si dibattono due concetti estetici e, in sostanza, due percorsi conoscitivi che perseguono due traiettorie opposte e contrarie: l'una sposa regolarità e virtù nel bello ideale, nella visione logica di simmetria e prospettiva; l'altra dall'irregolarità e frammentarietà della percezione trae un piacere esclusivamente visivo, definito da Gilpin con il suo concetto estetico di pittoresco" [Orestano 2003]. L'elemento della rovina assurge a componente essenziale per la consecuzione del pittoresco. Ciò avviene non in relazione alle qualità estetiche dell'oggetto in quanto tale, ma grazie alla sua peculiare caratteristica d'incompiutezza. L'imperfezione calata in contesti tanto armonici assume carattere di anomalia. La rovina emerge dalla perfezione del contesto, stridendo con esso diventa accumulatore ideale dello sguardo dell'osservatore che, vagando liberamente nella grazia equilibrata del paesaggio inscenato, ricade invariabilmente sull'elemento dissonante da cui è attratto e per il quale viene condotto ancora una volta verso traguardi più lontani nuovamente perfetti. Risulta possibile esperire l'effetto prodotto da questa tipologia di manufatti in siti quali il Regno Giardino di Worlitz o il Parco Reale di Laeken. In entrambi il tema della rovina viene declinato con forme e riferimenti diversi ma con l'intento comune,

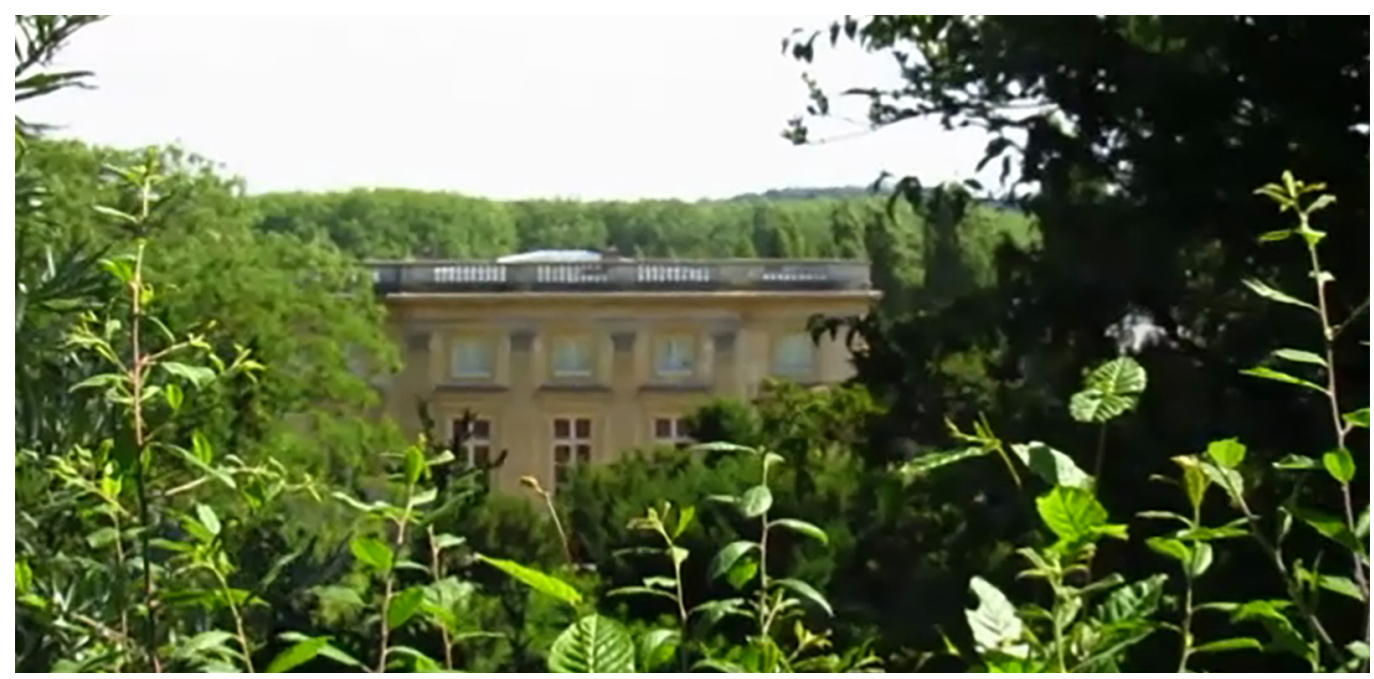


analogo al caso descritto da Gilpin per Stowe, di catturare l'attenzione, attraverso il prodotto dall'imperfezione insita al concetto di rovina per rafforzare la percezione di complessiva armonia dei paesaggi configurati. "Gilpin intende dimostrare come la gratificazione visiva non coincida con la virtù della lezione classica [...] ciò comporta l'avvento di una nuova idea estetica, noncurante della norma del bello ideale, fondata sulla nozione della fragilità della percezione e sul rapporto dialogico che l'occhio instaura con la natura. The Ruin seduce in quanto debole rappresentazione e insieme modello di tale fragilità, come possibilità di trasgressione epistemologica, ritorno al soggetto, al quale viene chiesto di contemplare, nell'intrico del paesaggio, l'enigma della sua essenza"' [Orestano 2003, p. 306]. La rovina diviene elemento tramite la cui visione è concesso all'osservatore praticare introspezione. Tale stato di cose corrobora il rapporto identitario tra natura e individuo e conferisce al giardino pittoresco la prerogativa di attore primario nel processo di scoperta e indagine tanto del paesaggio quanto dell'interiorità dell'osservatore.

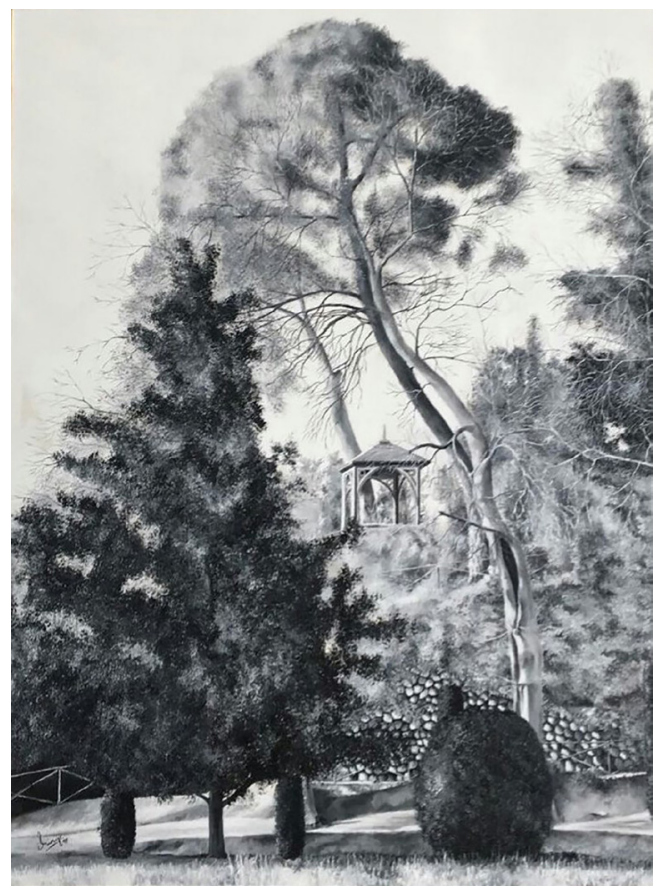

\section{Conclusioni}

La sovrapposizione dei dati ricavati dalle analisi delle fonti di tipo storico trattatistiche con quelli relativi allo studio dei giardini di paesaggio nelle loro consistenze presenti fa emergere come l'impiego degli elementi distintivi sintetizzati negli scritti degli autori settecenteschi conferisca a tali impianti dei canoni di elevata riconoscibilità. Lo studio, approfondito dei singoli elementi, svela la rete di conoscenze comuni e di scambi di informazioni avvenuti al fine della loro realizzazione. Le caratteristiche relative alla peculiare declinazione di tali dispositivi rende possibile approfondire come la grammatica comune, che costituisce la regola tipologica del giardino moderno, si presti flessibilmente a essere arricchita di particolari legati alla soggettiva interpretazione dell'apparato teorico, già fortemente presente alla fine del secolo dei Lumi, nonché alle connotazioni fisiche, morfologiche e ambientali proprie dei territori che ospitano i siti afferenti a questa categoria.

\section{Note}

[I]Tacito. Annales, Liber XV, 42.Traduzione italiana di Stefanoni M. Milano: Garzanti, 1990. 
Fig. 10. II Jardin del Principe di Aranjuez, il padiglione in stile neogotico posto a coronamento della collina artificiale per l'osservazione del paesaggio circostante, vista.

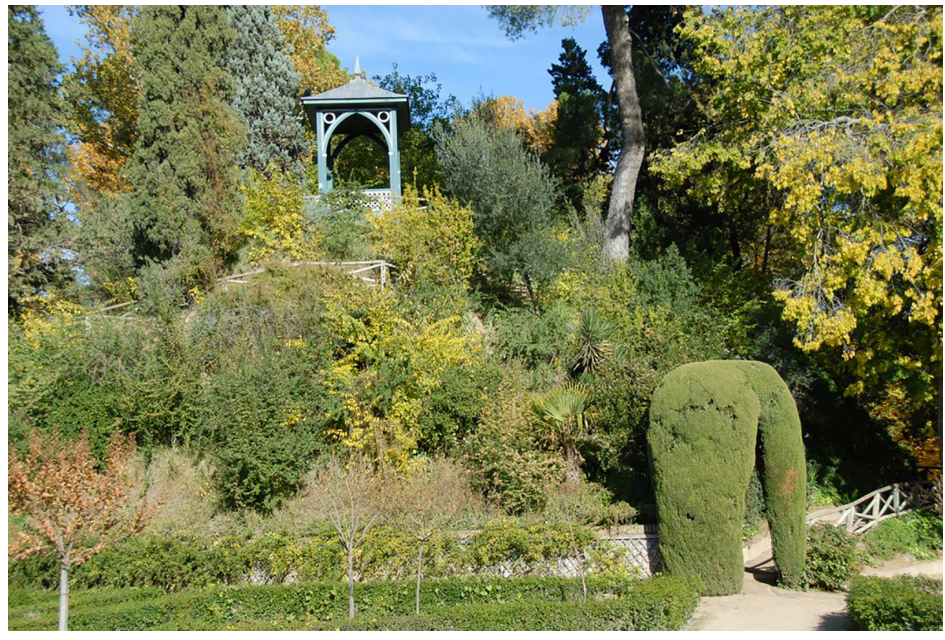

\section{Riferimenti bibliografici}

Álvarez De Quindós B. J. ( 1804$)$. Descripción histórica del Real Bosque y Casa de Aranjuez. Madrid: Imprenta Real.

Chías P., AbadT. (2019). Los territorios del rey:Aranjuez, entre la realidad y la ilusión. In P. Belardi (a cura di). Riflessioni, l'arte de disegno/il disegno dell'arte. Atti del $41^{\circ}$ Convegno Internazionale dei docenti delle discipline della rappresentazione, Perugia $19-21$ settembre 2019, pp. 543-552. Roma: Gangemi Editore.

Clément G. (20।3). Giardini, paesaggio e genio naturale. Macerata: Quodlibet.

Cundari C. (1998). Il disegno per l'analisi dell'architettura: Strumenti per il disegno dell'architettura. Roma: Kappa.

Duvernois C. (2008). Trianon: le domaine privé de Marie-Antoinette. Arles Parigi: Actes Sud.

Franci G., Zago E. (199|). Horace Walpole Saggio sul giardino moderno. Firenze: Casa Editrice Le Lettere.

Giannetti A. (2020). Place-makers, Costruttori di paesaggi tra Napoli e Worlitz. In F. Zecchino (a cura di). L'architettura del giardino in Europa. Evoluzione storica e nuove prospettive. Napoli: Artem.

Gilpin W. (1748). A dialogue upon the gardens of the Right Honourable the Lord Viscount Cobham, at Stowe in Buckinghamshire. Londra: B. Seeley.

Giordano P. (20 I 8a). II giardino inglese della Reggia di Caserta, il Petit Trianon di Versailles ed il parco di Worlitz: rilievi e disegni inediti. In Salerno R. (a cura di). Rappresentazione/Materiale/Immateriale. Atti del $40^{\circ}$ Convegno Internazionale dei Docenti della Rappresentazione. Milano, I3-15 settembre 2018, pp. 587-594. Roma: Gangemi Editore.

Giordano P. (20 | 8b). II verde monumentale come resistenza critica alla fragilità urbana. In AA. WV. (a cura di). IFAU 20 I 8 2nd International Forum on Architecture and Urbanism.Territori Fragili/Fragile Territories, pp. 728-735. Roma: Gangemi Editore.

Giordano P. (20 I 9). II disegno dei giardini all'Inglese in Europa, Caserta,Versailles e Worlitz. In Paesaggio Urbano, n. I, pp. I I 7- I 27. Santarcangelo di Romagna: Maggioli Editore.

Lablaude P.A. (1995). Les Jardins de Versailles. Lione: Nouvelles Éditions Scala.

Oers W. (2016). Capability Brown's Design for Schönenberg at Laeken near Brussels, I782. In Garden History, vol. 44, Supplement I: Capability brown: perception and response in a gloal context: the Proceedings of an ICOMOS-UK Conference held at the University of Bath, 7-9 September 2016, pp. 101-113. New York: Jstor.

Orestano F. (2003). II giardino pittoresco tra percezione e rappresentazione: Stowe e il Dialogo di William. In G. Guerci L. Pelissetti L. Scazzosi (a cura di). Oltre il giardino: le architetture vegetali e il paesaggio, pp. 263-274. Firenze: L.S. Olschki.

Van Ypersele De Strihou A. e P. (|99|). Laeken, un château de l'Europe des Lumières. Gembloux: Duculot.

Walpole H. ( 1785). Essay on Modern Gardening. Strawberry Hill:T. Kirgate.

\section{Autori}

Domenico Crispino, Università della Campania “LuigiVanvitelli”, domenico.crispino@unicampania.it Luigi Corniello, Università della Campania “LuigiVanvitelli”, luigi.corniello@unicampania.it

Per citare questo capitolo: Crispino Domenico, Corniello Luigi (202I). L'armonia del linguaggio dei Giardini Paesaggistici nell'Europa di fine Settecento/The harmony of language in landscape gardens in late Eighteenth-century Europe. In Arena A., Arena M., Mediati D., Raffa P. (a cura di). Connettere. Un disegno per annodare e tessere. Linguaggi Distanze Tecnologie. Atti del $42^{\circ}$ Convegno Internazionale dei Docenti delle Discipline della Rappresentazione/Connecting. Drawing for weaving relationship. Languages Distances Technologies. Proceedings of the $42^{\text {th }}$ International Conference of Representation Disciplines Teachers. Milano: FrancoAngeli, pp. 590-607. 


\title{
The Harmony of Language in Landscape Gardens in Late $18^{\text {th }}$ Century Europe
}

\author{
Domenico Crispino \\ Luigi Corniello
}

Abstract

The research aims to identify the methodological matrix that is the core of the realization of some of the landscape gardens developed in Europe at the end of the XVIII Century. trough the study of the graphic and theoretical apparatus, built during the same century, are analysed the sites of the Petit Trianon Park in Versailles, the Royal Park of Laeken in Brussels, the Kingdom-Garden of Wörlitz in Dessau and the Aranjuez Jardin del Principe on the southern border of the Community of Madrid. These items present a palimpsest of similar elements referring both to the network of relationships, that constitute the connection between the commissioners, and to certain fundamental principles set out by English authors such as Walpole and Gilpin. Some peculiarities emerged from the sources written by the two British Authors, done through their works articulation, which clearly do not intend to be linked to the whole treatises formulated in that period regarding the typological structure of the modern garden. Both authors distinguish this new category, freeing themselves from the search for objective descriptions typical of treatises, enriching their dissertations with a wide range of impressions and subjective opinions capable of providing a partial but more effective representation of the individual elements. This study have the purpose to examine, through the methodology of drawing discipline, the elements highlighted by the authors' descriptions that are identifiable within the analysed sites, demonstrating the individual elements capability to give their own identity characteristics to the whole typology.

Keywords

languages, landscape, drawing, garden, palimpsest.

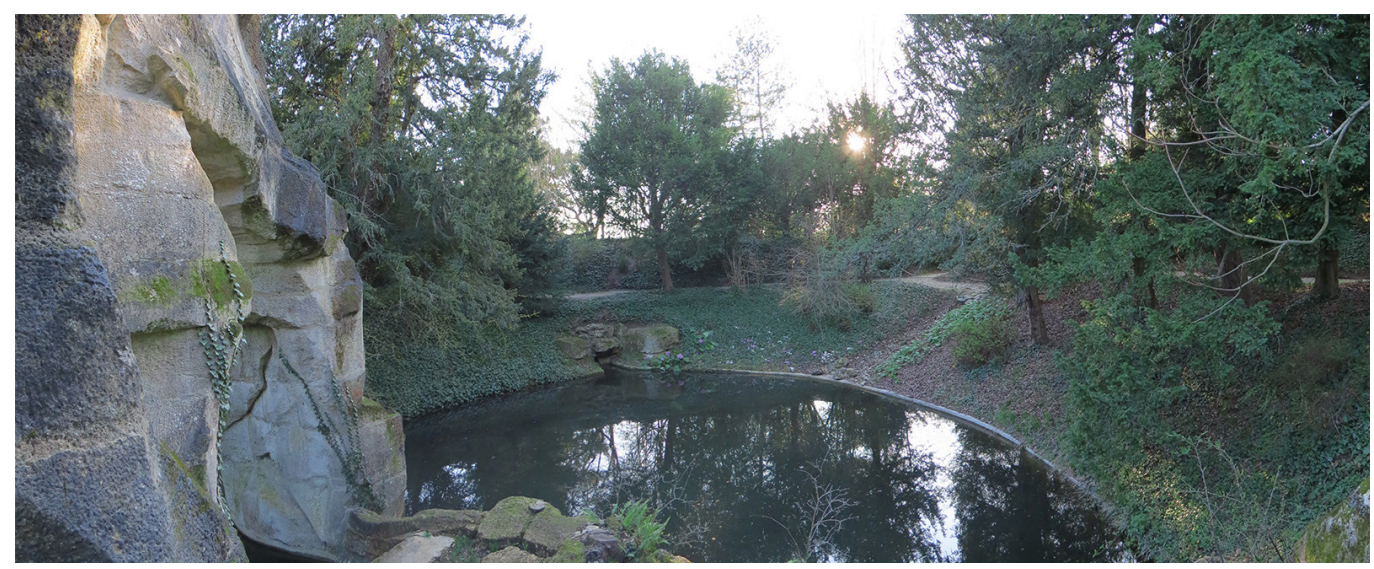




\section{Introduction}

The landscape garden, thought as an antithesis to the classic architectural system, have been established in Europe in the end of the XVIII Century. Starting from the English experience, acknowledged to have conceived this typological system, it is possible to distinguish a range of effective applications widespread in the continent and declined through the different morphological, climatic and environmental conditions offered by the different contexts hosting landscape gardens. However, the differences revealed by the analysis and comparison between the various sites can be linkable to an analogous typological matrix that refers to the methodology of the English garden. The aim of the study to reach a deeper knowledge of the theoretical and methodological links, sited at the base of the information network, already present in the eighteenth century and used for the practical dissemination of the theoretical and morphological apparatus. The studied sites are apparently distant and heterogeneous, but contrary to this, they are closely connected by a network that binds the patrons together with the designers and theorists who created the gardens. Through the analysis of documentary and graphic sources, the research aims to trace the actual existence of the network. First of all, it consists of the methodological and documental framework that formed the common basis for the formation of thought on the modern garden. Nevertheless, the research wants to identify the exchanges of information, experience and professionalism that, towards the end of the Enlightenment, made possible to draw up a wide catalogue of different experiences related to the landscape garden, and, in the meantime, that can be traced back to a single, clearly distinguishable disciplinary structure with strong identity characteristics. The presence of a strong theoretical component, that stands in the writings of various eighteenth-century authors [Walpole 1785; Gilpin 1748], makes it possible to verify the existence of a complex range of elements created in landscape gardens that can be referred to the common root of the treatise and that are able to be clearly recognised. The research is based on many scientific contributions that constitute a fertile base from which it is possible to draw data and to detect the presence of connections and mutual influences that occurred in the creation of the studied sites, such as the Petit Trianon in Versailles [Duvernois 2008; Lablaude 1995], the Parc Royal de Laeken in Brussels [Van Ypersele de Strihou 1991, Oers 2016], the Kingdom-Garden of Wörlitz [Giordano 2018; Giordano 2019; Giannetti 2020] and the Jardin del Principe in Aranjuez [Álvarez De Quindós I804; Chías Navarro, Abad 20 I9].

Fig. I. Landerer F., The Royal park of Laeken Plan Perspectif de la Campagne de Scoonenberg pres de Bruxelles appartenante LL.AA.RR. les Gouverneurs des Pays Bas, 1780. View.

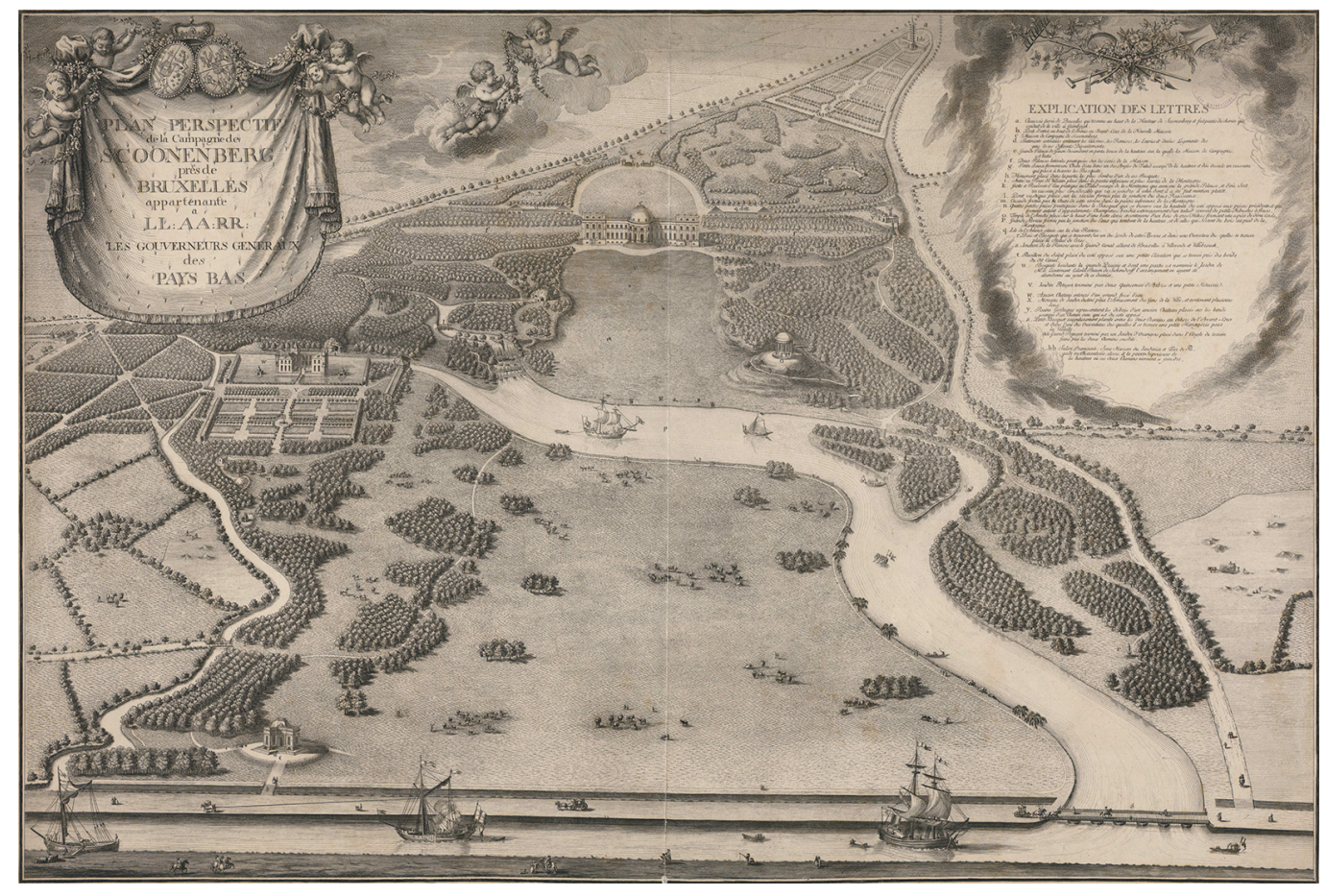




\section{Analysis of theoretical sources}

The research proposes the analysis of the theoretical sources of the I8th century and identifies the distinctive elements within the studied sites using the disciplinary tools of drawing for the knowledge of the territory, the landscape and the cultural heritage [Clément 2013; Cundari 1998; Giordano 20 I8b]. The Essay on Modern Gardening [Walpole 1785] is a text whose examination assumes particular value for the correct understanding of the evolutionary process that interested the subject of the garden in the period between the 17th and 19th centuries. The text in its Italian translation [Franci, Zago 1991] is presented as a treatment that looks for the origins of the modern conception of the garden, identifying its precursors in the classical period. The author conducts a sharp critique of the architectural garden, highlighting the paroxysms that built its methodological framework over time. The research identifies the founders of modern thought on the garden through the analysis of the sequence of refinements and reinterpretations that lead to the theoretical, methodological and applicative definition of the modern garden. Its first root refers to the work of the Latin Tacitus. Walpole, according to the Annales, asserts that Nero "discovered true good taste; and he had also discovered two men of true genius capable of putting his boldest ideas into practice. These ideas had anticipated the aesthetic principles of the modern garden" [Franci, Zago 1991, p. 105]. The discussion shows how this primordial impulse of typological approach had been forgotten and subsequently replaced by the architectural garden, which took on increasing relevance, making it necessary in the eighteenth century to create a critique able to trigger a change towards the modern garden. The main proponents of the transition from the old architectural garden, in the French or Italian style, to the modern landscape garden, in the English style, are identified in the figures of Bridgeman and Kent. Bridgeman is credited with the discovery and the use of a new perimeter device that replaces the wall with a less recognisable moat. The use of this innovative system called ah-ah allows the garden to merge with the surrounding landscape. The use of a similar device can be found in the perimeters of the various parks studied in this research.

In the Petit Trianon in Versailles, the apparatus that defines the perimeter is articulated in the coexistence of ah-ah, height differences and physical perimeter walls. This heteroge-

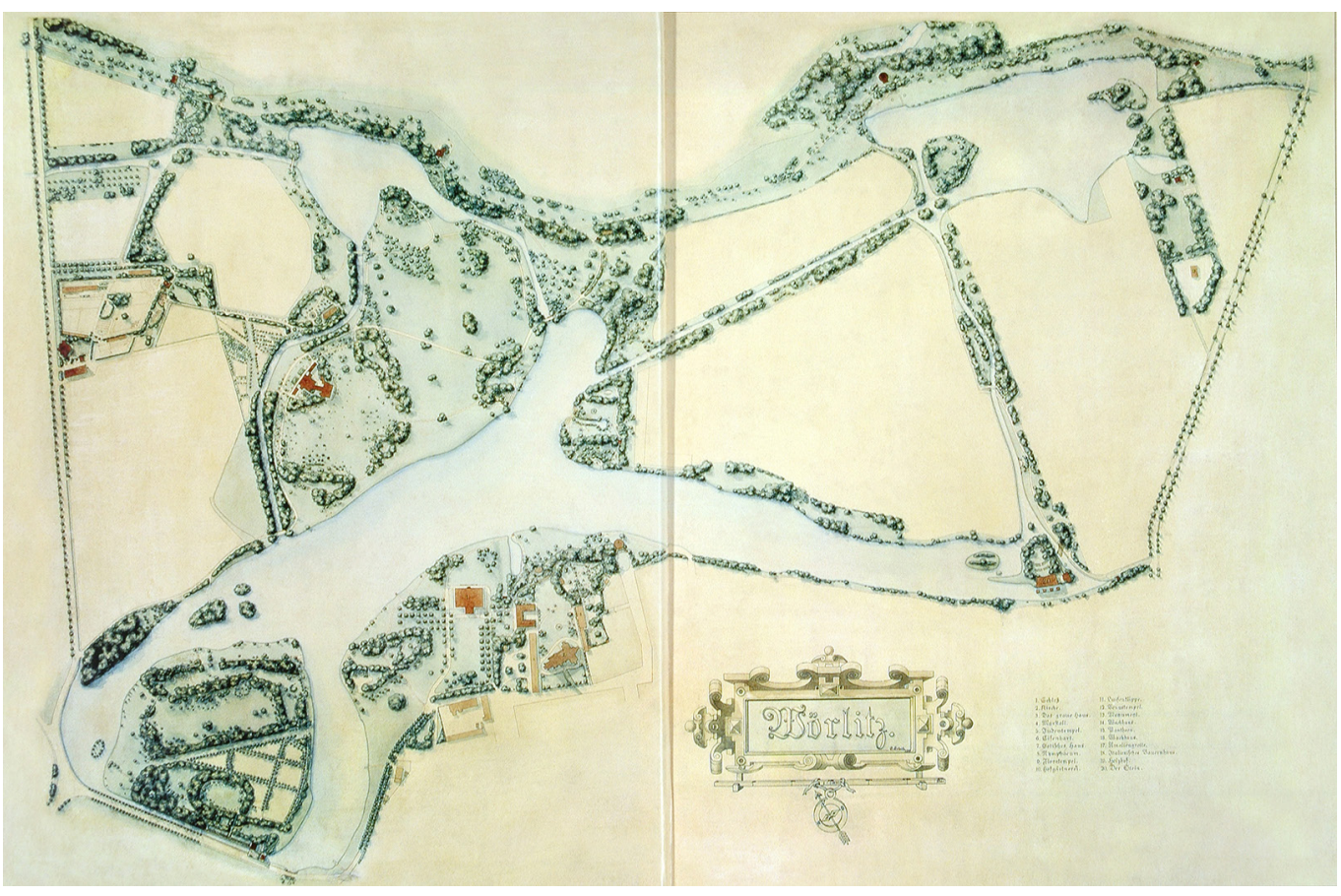


neous range of separation systems contributes to the creation of an impassable boundary which at the same time allows to look beyond the physical limit of the park, where the surrounding landscape manifests its capacity to enrich the prospectus, and furthermore it combines environment and garden in a single scene.

The Jardin del Principe in Aranjuez, south of the Spanish capital, has its limits in the southern fence separating it from Calle de la Reina and in the presence of the northern River Tagus. Although the watercourse is not a canonical ah-ah, as in Bridgeman's work in Stowe, it fulfils the same function, allowing the landscape on the opposite bank of the river to insinuate itself into the vegetation of the park sections, which are more oriented towards modern gardens. The use of water as an invisible barrier allows the surrounding area to become an essential complement to the scenarios offered by the landscape garden. Kent's work is characterised by the skilful use of water and the innovative adoption of orographic and vegetation arrangements. The English architect rejects the use of straight canals, geometric basins and fountains, and reinserts water into the palimpsest of the park as a pleasant stream that can creep naturally into the folds of the ground. With regard to the ground and the trees arrangement, Kent "understood that all nature was a garden. He felt the enchanting contrast between valley and hill where one turns into the other, he savoured the magic of a gentle convexity or a concave depression, he took note of the way in which uncultivated groves crowned a gentle rise with happy grace; and while they framed distant views between their harmonious trunks, at the same time they shifted and extended the perspective through an optical illusion" [Franci, Zago 1991, p. 84]. Lancelot Brown's design action in Laeken Park is an expression of the modern conception of the use of water masses to create systems oriented towards shapes in which nature is effectively applied. The watercourse cuts the park transversally, taking the laconic tone of a sinuous canal in the centre, after having been a thunderous waterfall in the previous section, because of a jump in height between the upper arm of the canal and the following one. In Brown's project, the water ends its course re-joining the navigable canal that stands as the south-eastern edge of the garden. The park design, according to Kent's experiences, takes advantage of the natural slope of the land between the location of the residence and the navigable waterway. Brown enriches the effective framework proposed by the natural

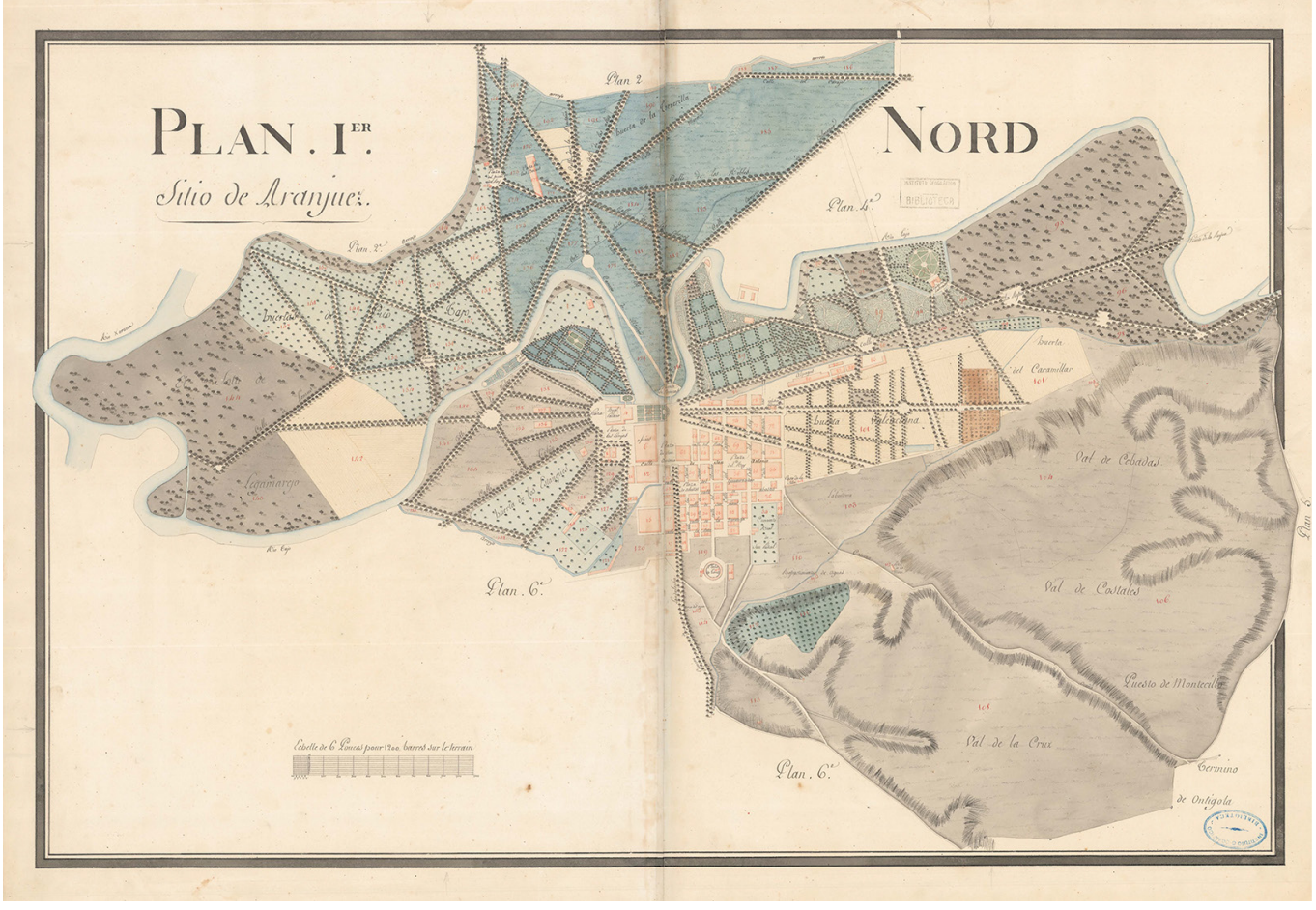


orography by the organic placement of groups of trees which allow the communication among the central peripheral and external elements of the park, through the main field, and that constitute two harmonious wings in order to orientate the perspective.

At Versailles, on the other hand, the construction of the Petit Trianon required considerable masses of land to move, trying to give the barren, flat ground the amount of movement necessary to articulate scenes designed to set up Marie-Antoinette's lieu du plaisir. The well-considered use of the orographic ground, enriched by the use of a wide range of tree species and the articulation of water in a network of canals, basins, nymphaea and little islands, makes it possible to set the wide range of landscapes suggested by the observation of nature.

The scenes are overlaid and the living independent elements of the distant landscape become the continuously changing background of the palimpsest organised by the landscape gardener. Englefield has been the first to theorise this concept, "he chose with singular good taste what constitutes the greatest beauty of a garden, the view of the most pleasing sights. [...] A beautiful, animated view is the scene that will always be most frequented, sacrificed in the past to the useful and the comfortable" [Franci, Zago 1991, pp. 95-96]. In order to make the surrounding landscape manifest and perceptible, in all the places covered by this analysis it is possible to identify preferential viewpoints that give concreteness to the union between park and context. The sites of Versailles and Aranjuez realise small hills at the top of which, in the French example, there is a small observation point which visually links the first section of the English garden with the Petit Trianon building and the Royal Park in the background; in the Spanish example, the crowning of the hill consists of a small wooden pavilion in neo-Gothic style which links the elements of the garden with the river on the border.

Fig. 4. Krafft J. Ch., The Royal park of Versailles, Plan général du jardin français et pittoresque du grand et petit Trianon Versailles, appartenant à So Majesté l'Empartenant à so Majesté general plan of Grand and
Petit Trianon parks, I 810.

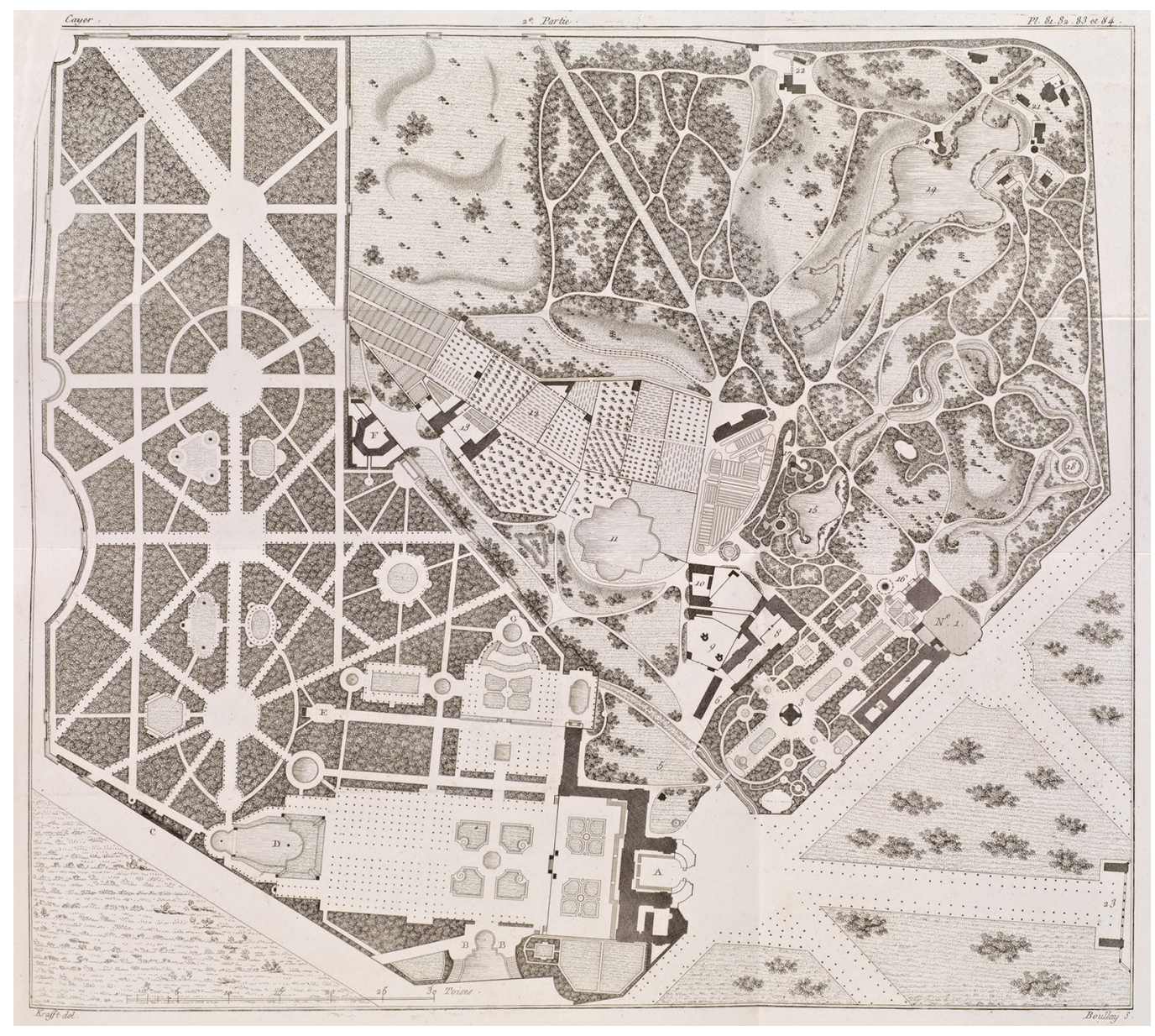




\section{Shapes and processes in eighteenth-century views}

The disciplinary evolution of the modern garden triggers a process of mimesis through which architects attempt to emulate the effects suggested by the natural landscape in their study and layout of new parks. This development is made possible by a research that aims to hide the artefacts that make reproduction feasible. The fundamental principle of this special practice is formulated by the author when he states that "the creator of the modern garden exercises all of his talent hiding his art" [Franci, Zago 199I, p. 92]. The element of mimesis is difficult to identify, and gardeners and landscape architects have put all their skills and experiences into the hiding of details that might not reveal the artificial nature of the devices used, even after the most acute observation.

An effective example of the efforts made in this hiding practice is to be found in the analysis of the Rocher placed at the side of the Belvedere in the gardens of the Petit Trianon where "the invoices of the archives attest several payments of money due to the painting of the Rocher. According to what had been done in similar gardens, this work was carried out in trompe-l'oeil with the colour of moss hiding the mortar joints between the ashlars and also to pretend the too new appearance of the construction" [Duvernois 2008, pp. 31-34].

The Dialogue upon the gardens of the Right Honourable the Lord Viscount Cobham [Gilpin 1748] is particularly important because of the peculiar critical vision that it offers of the landscape garden. The analysis of the issues is done cleverly through the divergent positions of the two protagonists. Among the most interesting aspects there is the consideration according to which the landscape garden stages "an experience of thin and well-orchestrated visual solicitations necessary to the decoding of monuments" [Orestano 2003, p. 297]. Therefore, the picturesque connotation emerges as an element able to catch the spectator's attention. Within the Dialogue this term appears through the voice of Polypthon when next

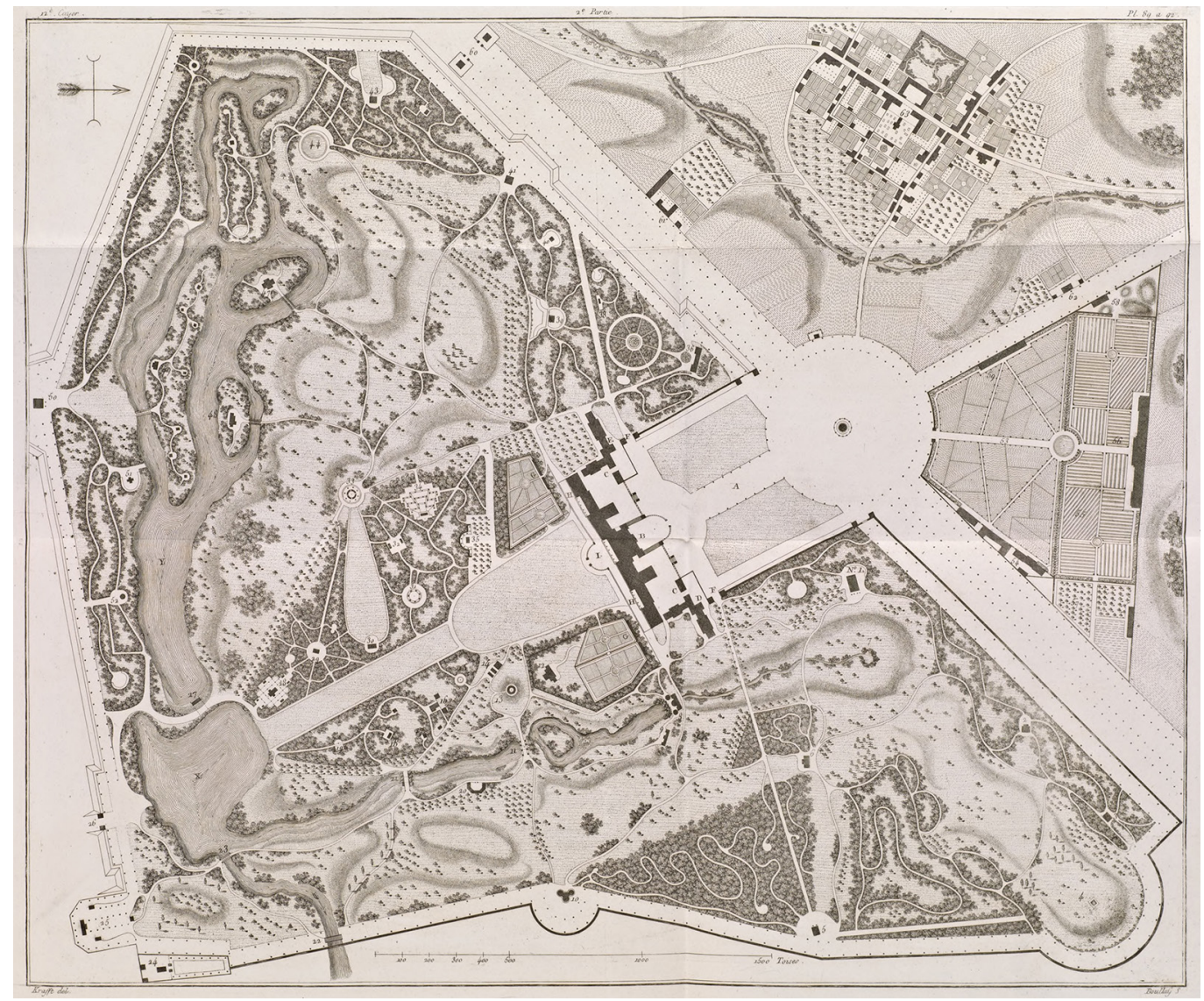


Fig. 6. The Petit Trianon Park of Versailles, the Ah-Ah device used to define the south-eastern (Doundary view (photo by D. Crispino, 2017).

Fig. 7.The Petit Trianon Park of Versailles, the Ah-Ah device used to interrupt the boundary wall along the northern edge, view (photo by D. Crispino, 2017)

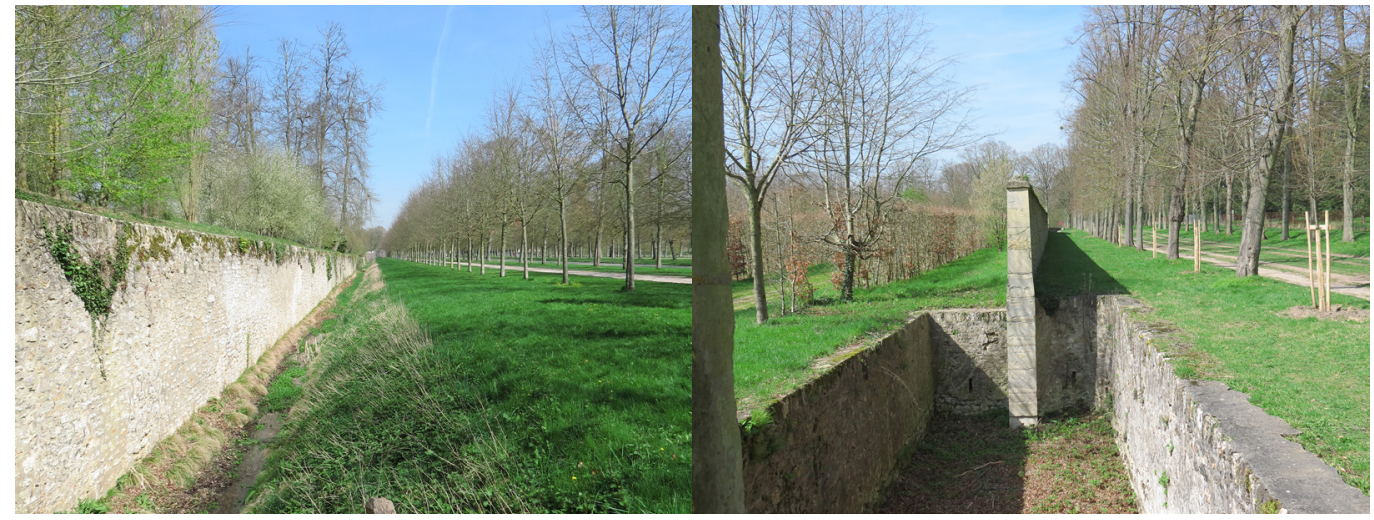

to the lake of the eleven acres he sees an object on the opposite shore that strikes him: "I think the Ruin a great Addition to the Beauty of the Lake. There is something so vastly picturesque and pleasing to the Imagination in such Objects, that they are a great Addition to every Landskip" [Gilpin I748, pp. 4, 5].

The term picturesque, linked to the concept of ruin by these statements, becomes "the point of a debate that does not have as its object the beauty, but the strange, intriguing, picturesque effect that imperfection inspires in the viewer. [...] There are debated two aesthetic concepts and two cognitive paths that pursue two opposite and contrary trajectories: one marries regularity and virtue in the ideal beauty, in the logical vision of symmetry and perspective; the other draws, from the irregularity and fragmentary nature of perception, an exclusively visual pleasure, defined by Gilpin within his aesthetic concept of the picturesque" [Orestano 2003]. The ruin element becomes an essential component for the execution of the picturesque. This happens not in relation to the aesthetic qualities of the object, but thanks to its distinctive characteristic of incompleteness. The imperfection dropped in such harmonious contexts assumes the character of anomaly. The ruin emerges from the perfection of the context, contrasting with it. This way the ruin becomes an ideal storage for the observer's glance which, while freely wanders in the balanced grace of the staged landscape, inevitably falls on the dissonant attracting element through which it is led once again towards more distant and perfect goals. It is possible to experience the effect produced by this type of artifacts in sites such as the Garden Kingdom of Worlitz or the Royal Park of Laeken. In both, the theme of the ruin is declined in different ways but with the common intent, similar to the case described by Gilpin for Stowe, to capture the attention through the product

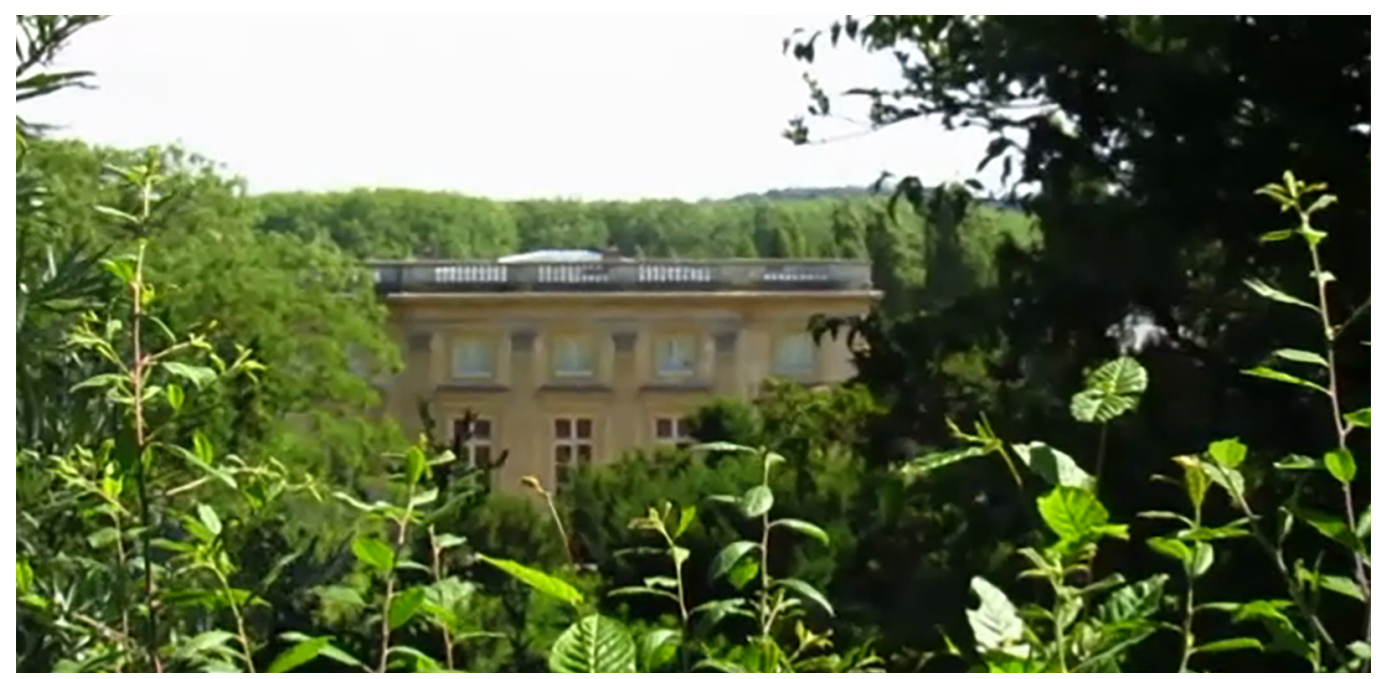

Fig. 8: The Petit Trianon Park of Versailles, the landscape from the artificial hill built on the western edge of the first section of the park, view photo by D. Crispino, 2017) 
of the imperfection implicit in the concept of ruin, in order to strengthen the perception of the overall harmony in the configured landscapes. "Gilpin intends to demonstrate how visual gratification does not coincide with the virtue of the classical lesson [...] this leads to the development of a new aesthetic idea, disregarding the standard of ideal beauty, based on the notion of the weakness of perception and on the dialogical relationship that the eye establishes with nature. The 'ruin' seduces because it is a weak representation and at the same time a model of such a weakness, as a possibility of epistemological transgression, a return to the subject, who is asked to contemplate the essence of the enigma, in the tangle of the landscape" [Orestano, 2003, p. 306]. The 'ruin' becomes an element through whose vision the observer is allowed to practice introspection. This state of affairs strengthens the relationship between nature and individual identity and gives the picturesque garden the status of primary actor in the discovery and investigation process of both the landscape and the interiority of the observer.

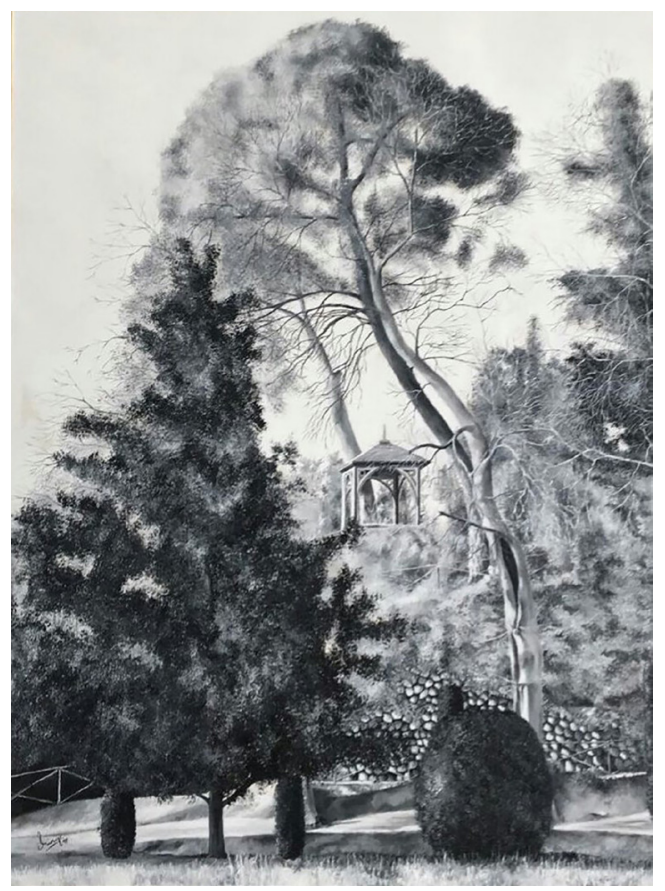

\section{Conclusions}

The combination of the data obtained from the analysis of the historical sources of treatises, with those relating to the study of landscape gardens in their present consistencies, shows how the use of the distinctive elements summarized in the writings of the 18th Century authors gives to these work canons of high recognizability. The detailed study of the single elements reveals the network of common knowledge and exchange of information that occurred in order to realize them. The characteristics related to the peculiar declination of these devices makes it possible to investigate how the common grammar, which is the rule of the modern garden typology, may be flexibly enriched with details related to the personal interpretation of the theoretical apparatus, already strongly present at the end of the Enlightenment, as well as the physical, morphological and environmental connotations of the territories hosting the sites of this category.

\section{Notes}

[I]Tacito. Annales, Liber XV, 42. Italian translation by Stefanoni M. Milano: Garzanti, 1990 
Fig. 10. The Jardin del Principe of Aranjuez, the neo-gothic style pavilion crowning the artificial hill to observe the surrounding landscape, view.

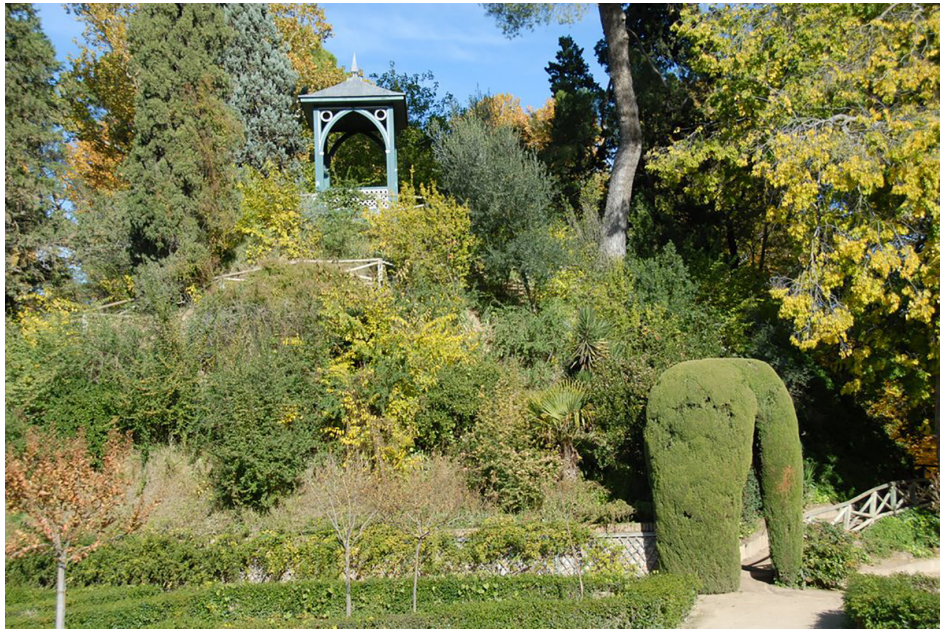

\section{References}

Álvarez De Quindós B. J. ( 804$)$. Descripción histórica del Real Bosque y Casa de Aranjuez. Madrid: Imprenta Real.

Chías Navarro P., AbadT. (2019). Los territorios del rey:Aranjuez, entre la realidad y la ilusión. In P. Belardi (a cura di). Riflessioni, l'arte del disegnolil disegno dell'arte. Atti del $41^{\circ}$ Convegno Internazionale dei docenti delle discipline della rappresentazione, Perugia 19-2I settembre 2019, pp. 543-552. Roma: Gangemi Editore.

Clément G. (20|3). Giardini, paesaggio e genio naturale. Macerata: Quodlibet.

Cundari C. ( 1998). Il disegno per l'analisi dell'architettura: Strumenti per il disegno dell'architettura. Roma: Kappa.

Duvernois C. (2008). Trianon: le domaine privé de Marie-Antoinette. Arles Parigi: Actes Sud.

Franci G., Zago E. (199|). Horace Walpole Saggio sul giardino moderno. Firenze: Casa Editrice Le Lettere.

Giannetti A. (2020). Place-makers, Costruttori di paesaggi tra Napoli e Worlitz. In F. Zecchino (a cura di). L'architettura del giardino in Europa. Evoluzione storica e nuove prospettive. Napoli: Artem.

Gilpin W. (1748). A dialogue upon the gardens of the Right Honourable the Lord Viscount Cobham, at Stowe in Buckinghamshire. Londra: B. Seeley.

Giordano P. (20 18a). II giardino inglese della Reggia di Caserta, il Petit Trianon di Versailles ed il parco di Worlitz: rilievi e disegni inediti. In Salerno R. (a cura di). Rappresentazione/Materiale/Immateriale. Atti del $40^{\circ}$ Convegno Internazionale dei Docenti della Rappresentazione. Milano, I3-15 settembre 2018, pp. 587-594. Roma: Gangemi Editore.

Giordano P. (20|8b). II verde monumentale come resistenza critica alla fragilità urbana. In AA.VV. (a cura di). IFAU 2018 2nd International Forum on Architecture and Urbanism.Territori Fragili/Fragile Territories, pp. 728-735. Roma: Gangemi Editore.

Giordano P. (20 I 9). II disegno dei giardini all'Inglese in Europa, Caserta,Versailles e Worlitz. In Paesaggio Urbano, n. I, pp. I I 7- I 27. Santarcangelo di Romagna: Maggioli Editore.

Lablaude P.A. (1995). Les Jardins de Versailles. Lione: Nouvelles Éditions Scala.

Oers W. (2016). Capability Brown's Design for Schönenberg at Laeken near Brussels, I782. In Garden History, vol. 44, Supplement I: Capability brown: perception and response in a gloal context: the Proceedings of an ICOMOS-UK Conference held at the University of Bath, 7-9 September 2016, pp. I01-113. New York: Jstor.

Orestano F. (2003). II giardino pittoresco tra percezione e rappresentazione: Stowe e il Dialogo di William. In G. Guerci L. Pelissetti L. Scazzosi (a cura di). Oltre il giardino: le architetture vegetali e il paesaggio, pp. 263-274. Firenze: L.S. Olschki.

Van Ypersele De Strihou A. e P. (|99|). Laeken, un château de l'Europe des Lumières. Gembloux: Duculot.

Walpole H. ( 1785). Essay on Modern Gardening. Strawberry Hill:T. Kirgate.

\section{Authors}

Domenico Crispino, Università della Campania “LuigiVanvitelli”, domenico.crispino@unicampania.it Luigi Corniello, Università della Campania “Luigi Vanvitelli”, luigi.corniello@unicampania.it

To cite this chapter. Crispino Domenico, Corniello Luigi (2021). L'armonia del linguaggio dei Giardini Paesaggistici nell'Europa di fine Settecento/ The harmony of language in landscape gardens in late Eighteenth-century Europe. In Arena A., Arena M., Mediati D., Raffa P. (a cura di). Connettere Un disegno per annodare e tessere. Linguaggi Distanze Tecnologie. Atti del $42^{\circ}$ Convegno Internazionale dei Docenti delle Discipline della Rappresentazione/Connecting. Drawing for weaving relationship. Languages Distances Technologies. Proceedings of the $42^{\text {th }}$ International Conference of Representation Disciplines Teachers. Milano: FrancoAngeli, pp. 590-607. 